\title{
Oxidative capacity and radical chemistry in the polluted atmosphere of Hong Kong and Pearl River Delta region: analysis of a severe photochemical smog episode
}

\author{
Likun Xue ${ }^{1}$, Rongrong Gu${ }^{1}$, Tao Wang ${ }^{2,1}$, Xinfeng Wang ${ }^{1}$, Sandra Saunders ${ }^{3}$, Donald Blake ${ }^{4}$, Peter K. K. Louie ${ }^{5}$, \\ Connie W. Y. Luk ${ }^{5}$, Isobel Simpson ${ }^{4}$, Zheng Xu${ }^{1}$, Zhe $\mathrm{Wang}^{2}$, Yuan $\mathrm{Gao}^{2}$, Shuncheng Lee ${ }^{2}$, Abdelwahid Mellouki ${ }^{1}$, \\ and Wenxing Wang ${ }^{1}$ \\ ${ }^{1}$ Environment Research Institute, Shandong University, Ji'nan, Shandong, China \\ ${ }^{2}$ Department of Civil and Environmental Engineering, Hong Kong Polytechnic University, Hong Kong, China \\ ${ }^{3}$ School of Chemistry and Biochemistry, University of Western Australia, WA, Australia \\ ${ }^{4}$ Department of Chemistry, University of California at Irvine, Irvine, CA, USA \\ ${ }^{5}$ Environmental Protection Department, the Government of Hong Kong Special Administrative Region, Hong Kong, China
}

Correspondence to: Likun Xue (xuelikun@sdu.edu.cn)

Received: 8 February 2016 - Published in Atmos. Chem. Phys. Discuss.: 15 February 2016

Revised: 11 June 2016 - Accepted: 17 July 2016 - Published: 8 August 2016

\begin{abstract}
We analyze a photochemical smog episode to understand the oxidative capacity and radical chemistry of the polluted atmosphere in Hong Kong and the Pearl River Delta (PRD) region. A photochemical box model based on the Master Chemical Mechanism (MCM v3.2) is constrained by an intensive set of field observations to elucidate the budgets of $\mathrm{RO}_{x}\left(\mathrm{RO}_{x}=\mathrm{OH}+\mathrm{HO}_{2}+\mathrm{RO}_{2}\right)$ and $\mathrm{NO}_{3}$ radicals. Highly abundant radical precursors (i.e. $\mathrm{O}_{3}, \mathrm{HONO}$ and carbonyls), nitrogen oxides $\left(\mathrm{NO}_{x}\right)$ and volatile organic compounds (VOCs) facilitate strong production and efficient recycling of $\mathrm{RO}_{x}$ radicals. The $\mathrm{OH}$ reactivity is dominated by oxygenated VOCs (OVOCs), followed by aromatics, alkenes and alkanes. Photolysis of OVOCs (except for formaldehyde) is the dominant primary source of $\mathrm{RO}_{x}$ with average daytime contributions of $34-47 \%$. HONO photolysis is the largest contributor to $\mathrm{OH}$ and the second-most significant source (19-22\%) of $\mathrm{RO}_{x}$. Other considerable $\mathrm{RO}_{x}$ sources include $\mathrm{O}_{3}$ photolysis (11-20\%), formaldehyde photolysis (10-16\%), and ozonolysis reactions of unsaturated VOCs (3.9-6.2\%). In one case when solar irradiation was attenuated, possibly by the high aerosol loadings, $\mathrm{NO}_{3}$ became an important oxidant and the $\mathrm{NO}_{3}$-initiated VOC oxidation presented another significant $\mathrm{RO}_{x}$ source $(6.2 \%)$ even during daytime. This study suggests the possible impacts of daytime $\mathrm{NO}_{3}$ chemistry in the polluted atmospheres under con-
\end{abstract}

ditions with the co-existence of abundant $\mathrm{O}_{3}, \mathrm{NO}_{2}$, VOCs and aerosols, and also provides new insights into the radical chemistry that essentially drives the formation of photochemical smog in the high- $\mathrm{NO}_{x}$ environment of Hong Kong and the PRD region.

\section{Introduction}

The hydroxyl radical $(\mathrm{OH})$ and hydro/organic peroxy radicals $\left(\mathrm{HO}_{2}\right.$ and $\left.\mathrm{RO}_{2}\right)$, collectively known as $\mathrm{RO}_{x}$, play a central role in atmospheric chemistry and air pollution (Stone et al., 2012). They dominate the oxidative capacity of atmosphere, and hence govern the removal of primary contaminants and formation of secondary pollutants such as ozone $\left(\mathrm{O}_{3}\right)$ and secondary organic aerosol (Hofzumahaus et al., 2009). In the troposphere, they arise from photolysis of closed-shell molecules such as $\mathrm{O}_{3}$, nitrous acid (HONO), formaldehyde (HCHO) and other carbonyls, as well as ozonolysis reactions of unsaturated volatile organic compounds (VOCs) (Dusanter et al., 2009; Lu et al., 2012; Volkamer et al., 2010). In the presence of nitrogen oxides $\left(\mathrm{NO}_{x}\right)$ and VOCs, the $\mathrm{RO}_{x}$ radicals can undergo efficient recycling (e.g. $\mathrm{OH} \rightarrow \mathrm{RO}_{2} \rightarrow \mathrm{RO} \rightarrow \mathrm{HO}_{2} \rightarrow \mathrm{OH}$ ) and produce $\mathrm{O}_{3}$ and oxygenated VOCs (OVOCs) (Sheehy et al., 2010). 
The radical recycling is terminated by their cross reactions with $\mathrm{NO}_{x}$ (under high- $\mathrm{NO}_{x}$ conditions) and $\mathrm{RO}_{x}$ themselves (under low- $\mathrm{NO}_{x}$ conditions), which results in the formation of nitric acid, organic nitrates and peroxides (Liu et al., 2012; Wood et al., 2009). Given the essential significance and complex processes involved, radical chemistry presents one of the core areas in the atmospheric chemistry research.

Understanding the sources and chemistry of $\mathrm{RO}_{x}$ has long been a focus of air quality studies over the past decades. It has been shown that although air pollution problems are visually quite similar, the radical chemistry, and in particular the relative importance of primary radical sources, is inhomogeneous in different metropolitan areas. For example, the dominant radical sources are $\mathrm{O}_{3}$ photolysis in the South Coast Air Basin in California (2010 scenario) and Nashville, US (Martinez et al., 2003; Volkamer et al., 2010); HONO photolysis in New York City, US (Ren et al., 2003), Paris, France (Michoud et al., 2012) and Santiago, Chile (Elshorbany et al., 2009); HCHO photolysis in Milan, Italy (Alicke et al., 2002); and OVOC photolysis in Mexico City, Mexico (Volkamer et al., 2010), Beijing, China (Liu et al., 2012), Birmingham (summer scenario; Emmerson et al., 2005) and London in England (Emmerson et al., 2007) (note that HONO was not in situ measured but simulated by a box model in Emmerson et al. $(2005,2007)$, and hence the contributions of HONO photolysis might be underestimated). Therefore, identification of the principal radical sources is a fundamental step towards understanding the formation of air pollution and formulating science-based control strategies.

The nitrate radical $\left(\mathrm{NO}_{3}\right)$ is another important oxidant in the polluted atmosphere (Geyer et al., 2001). The $\mathrm{NO}_{3}$ initiated degradation of VOCs presents an important source of $\mathrm{RO}_{2}$, gaseous organic nitrates and nitrogen-containing aerosols (Rollins et al., 2012; Saunders et al., 2003). $\mathrm{NO}_{3}$ has been recognized as a major player in nocturnal chemistry, but is usually neglected for the daytime chemistry given its fast photolysis in sunlight (Volkamer et al., 2010). Under certain conditions, e.g. with abundant $\mathrm{O}_{3}$ and $\mathrm{NO}_{2}$ (hence strong $\mathrm{NO}_{3}$ production) and weak solar radiation (thus weak photolysis), however, $\mathrm{NO}_{3}$ may also play a role in the daytime chemistry. Indeed, Geyer et al. (2003) observed by differential optical absorption spectroscopy (DOAS) $\sim 5 \mathrm{pptv}$ of $\mathrm{NO}_{3} 3 \mathrm{~h}$ before sunset in Houston, and indicated considerable contribution $(10 \%)$ of $\mathrm{NO}_{3}$ chemistry to the daytime $\mathrm{O}_{x}$ loss. More studies are required to confirm the possible operation of $\mathrm{NO}_{3}$ chemistry during daytime and to evaluate its impacts on the atmospheric oxidative capacity (AOC) and formation of $\mathrm{O}_{3}$ and secondary aerosols.

Hong Kong and the adjacent Pearl River Delta (PRD) is the most industrialized region of southern China, and is suffering from serious photochemical air pollution (e.g. Ling et al., 2014; Zheng et al., 2010). A number of studies have been conducted in the last decade, most of which focused on either $\mathrm{O}_{3}$-precursor relationships (Zhang et al., 2007; Zhang et al., 2008) or local vs. regional contributions (Wang et al., 2009;
Li et al., 2012; Xue et al., 2014b), but few have attempted to understand the atmospheric oxidizing capacity and radical chemistry (Lu et al., 2014). Recent studies have observed the highest ever-reported concentrations of $\mathrm{OH}$ and $\mathrm{HO}_{2}$ at a rural site in the northern PRD, which cannot be reproduced by the classic knowledge of atmospheric chemistry (Hofzumahaus et al., 2009). This indicates the strong oxidative capacity of atmosphere in this region as well as a deficiency in understanding the chemistry underlying the pollution.

As part of the Hong Kong Supersite programme aimed at elucidating the causes of regional smog and haze pollution, an intensive field campaign was conducted at a regional receptor site in summer 2011. A comprehensive set of measurements was taken, which facilitated the construction of a detailed observation-constrained box model to study the atmospheric photochemistry. In the present work, we analyze a severe photochemical episode occurring during 25-31 August 2011 to gain an understanding of atmospheric oxidative capacity and radical chemistry. We first provide an observational overview of the episode, and then evaluate the chemical budgets of both $\mathrm{RO}_{x}$ and $\mathrm{NO}_{3}$ radicals. This study provides some new insights regarding: (1) the potential impact of $\mathrm{NO}_{3}$ on the daytime photochemistry in polluted atmospheres and (2) the primary radical sources of $\mathrm{RO}_{x}$ in the high- $\mathrm{NO}_{x}$ environment of Hong Kong and the PRD region.

\section{Methods}

\subsection{Experimental}

The measurements were conducted at the Tung Chung air quality monitoring station $\left(\mathrm{TC} ; 113.93^{\circ} \mathrm{E}, 22.30^{\circ} \mathrm{N}\right)$. It is located about $3 \mathrm{~km}$ south of the Hong Kong International airport, and is in a residential area of a new town in western Hong Kong (see Fig. S1 in the Supplement). This station is characterized as a polluted receptor site as it receives urban plumes from Hong Kong under easterly winds and regional air masses from the PRD region when northerly winds prevail, and is the location where the maximum $\mathrm{O}_{3}$ levels are usually recorded in Hong Kong (Xue et al., 2014b). Details of this station and analyses of HONO and aerosol data have been described in our previous publications (Xu et al., 2015; Xue et al., 2014b; Zhou et al., 2014).

A 1-month campaign was carried out from 6 August to 7 September 2011, which covered two distinct types of meteorological conditions and air quality (see Fig. 1). For the majority of the campaign, Hong Kong was influenced by clean marine air masses and featured by good air quality (typical summer conditions as a result of the Asian monsoon). In contrast from 25-31 August, a heavy multi-day photochemical smog event hit Hong Kong with northerly winds prevailing during the daytime and elevated concentrations of various air pollutants were observed. In the present study, this episode was subject to a detailed modeling analysis to understand 
the atmospheric oxidative capacity and $\mathrm{RO}_{x}$ chemistry, made possible with the most comprehensive suite of measurements taken for the first time in Hong Kong.

A full suite of trace gases and meteorological parameters were simultaneously measured during this episode (as summarized in Supplement Table S1). Here a brief description is given of the measurements used in the present study. Major air quality target pollutants were routinely monitored with commercial analyzers: $\mathrm{O}_{3}$ with a UV photometric analyzer (TEI model 49i); $\mathrm{CO}$ with a non-dispersive infrared equipment (API model 300EU); $\mathrm{NO}$ and $\mathrm{NO}_{2}$ with a chemiluminescence analyzer (TEI model 42i) equipped with a selective blue light converter (Xu et al., 2013). $\mathrm{NO}_{y}$ was measured by another chemiluminescence instrument (TEI model 42cy) with an external molybdenum oxide (MoO) catalytic converter (Xue et al., 2011). HONO was measured in real-time by a long path absorption photometer (QUMA model LOPAP-03) (Xu et al., 2015). Nitryl chloride $\left(\mathrm{ClNO}_{2}\right)$ was detected using a custom-built chemical ionization mass spectrometer (CIMS; THS Instruments Inc., Atlanta) (Tham et al., 2014). Peroxyacetyl nitrate (PAN) was measured by the same CIMS instrument with a heated inlet, and the potential interference caused by high NO was corrected based on laboratory tests (Slusher et al., 2004; Wang et al., 2014). Hydrogen peroxide $\left(\mathrm{H}_{2} \mathrm{O}_{2}\right)$ and organic peroxides were measured by an enzyme-catalyzed fluorescence instrument (Aerolaser AL-2021) (Guo et al., 2014). Particle number and size distributions in the range of $5 \mathrm{~nm}$ to $10 \mu \mathrm{m}$, which were used to calculate the aerosol surface density, were measured with a wide-range particle spectrometer (WPS; MSP model 1000XP) (Gao et al., 2009).

$\mathrm{C}_{2}-\mathrm{C}_{10}$ non-methane hydrocarbons were measured at a time interval of $30 \mathrm{~min}$ by a commercial analyzer that combines gas chromatography (GC) with photoionization detection (PID) and flame-ionization detection (FID) (Syntech Spectras, model GC955 Series 600/800 POCP). The detection limits for the measured VOCs ranged from 0.001 to 0.19 ppbv. In addition, $24 \mathrm{~h}$ whole air canister samples were collected on selected days (e.g. 25 and 29 August) for the detection of $\mathrm{C}_{1}-\mathrm{C}_{10}$ hydrocarbons by using GC with FID, electron capture detection (ECD) and mass spectrometry detection (MSD). The analyses were carried out at the laboratory of the University of California at Irvine, and the detection limit was 3 pptv for all measured species (Simpson et al., 2010; Xue et al., 2013). As evaluated in our previous study, both sets of hydrocarbon measurements agree very well apart from the alkenes. Here the real-time data tended to systematically overestimate the canister measurements (Xue et al., 2014b). Considering the generally lower detection limit of the canister observations, the high-resolution real-time data were corrected in the present study according to the canister data. $\mathrm{C}_{1}-\mathrm{C}_{8}$ carbonyls were measured by collecting air samples on DNPH-coated sorbent cartridges followed by high pressure liquid chromatography analysis (Xue et al., 2014c). For the carbonyls, a $24 \mathrm{~h}$ integrated sample was collected on
25 August, and eight $3 \mathrm{~h}$ samples were taken throughout the day on 31 August. The measured hydrocarbon and carbonyl species are listed in Table 1.

Meteorological parameters were monitored by a series of commercial sensors, including a probe for ambient temperature and relative humidity (Young RH/T probe) and an ultrasonic sensor for wind speed and direction (Gill WindSonic). Photolysis frequency of $\mathrm{NO}_{2}\left(J_{\mathrm{NO}_{2}}\right)$ was measured with a filter radiometer (Meteorologie Consult gmbh). All of the above techniques have been validated and applied in many previous studies, with detailed descriptions of the measurement principles, quality assurance and control procedures provided elsewhere (Guo et al., 2014; Xu et al., 2015; Xue et al., 2011, 2014a, b and c). See also Table S1 for a summary of the measurement techniques/instruments and time resolutions.

\subsection{The OBM-AOCP model}

The zero-dimensional chemical box model OBM-AOCP (Observation-Based Model for investigating the Atmospheric Oxidative Capacity and Photochemistry) has been utilized in many previous studies to evaluate $\mathrm{O}_{3}$ production (Xue et al., 2013, 2014a, b), PAN formation (Xue et al., 2014c), and oxidative capacity (Xue et al., 2015). Briefly, the model is built on the Master Chemical Mechanism (MCM; v3.2), a nearly explicit gas phase mechanism describing the degradation of 143 primary VOCs (Jenkin et al., 2003; Saunders et al., 2003), and is updated to include both a heterogeneous chemistry scheme (including heterogeneous processes of $\mathrm{NO}_{2}, \mathrm{NO}_{3}, \mathrm{~N}_{2} \mathrm{O}_{5}, \mathrm{HO}_{2}$, and $\mathrm{ClONO}_{2}$; Xue et al., 2014a) and a chlorine chemistry module that describes the reactions of $\mathrm{Cl}$ radical with various VOC compounds (Xue et al., 2015; note that the basic MCM only considers the reactions of $\mathrm{Cl}$ radical with alkanes). In addition to the chemistry, dry deposition and dilution mixing within the boundary layer are also included in the model (Xue et al., 2014a). The mixing layer height affecting the deposition rate and dilution mixing was assumed to vary from $300 \mathrm{~m}$ at night to $1500 \mathrm{~m}$ in the afternoon. Sensitivity model runs with different maximum mixing heights $(1000$ and $2000 \mathrm{~m})$ indicated that its impacts on the modeling results (e.g. simulated $\mathrm{HO}_{x}$ concentrations and $\mathrm{OH}$ production rate) were negligible. A detailed description of the model set up is provided in the Supplement.

The model is capable of simulating the concentrations of highly reactive species (e.g. radicals) and quantitatively evaluating several key aspects of atmospheric photochemistry such as oxidant formation (e.g. $\mathrm{O}_{3}$ and PAN), VOC oxidation and radical budgets. In our model, the rates of over 15600 reactions out of the full MCM (v3.2) are individually and instantaneously computed and grouped into a relatively small number of major routes. The calculation of ozone and PAN production rates have been described elsewhere (Xue et al., 2014a, c). Here the emphasis is placed on the computation of $\mathrm{AOC}$ and $\mathrm{RO}_{x}$ budget. AOC is cal- 


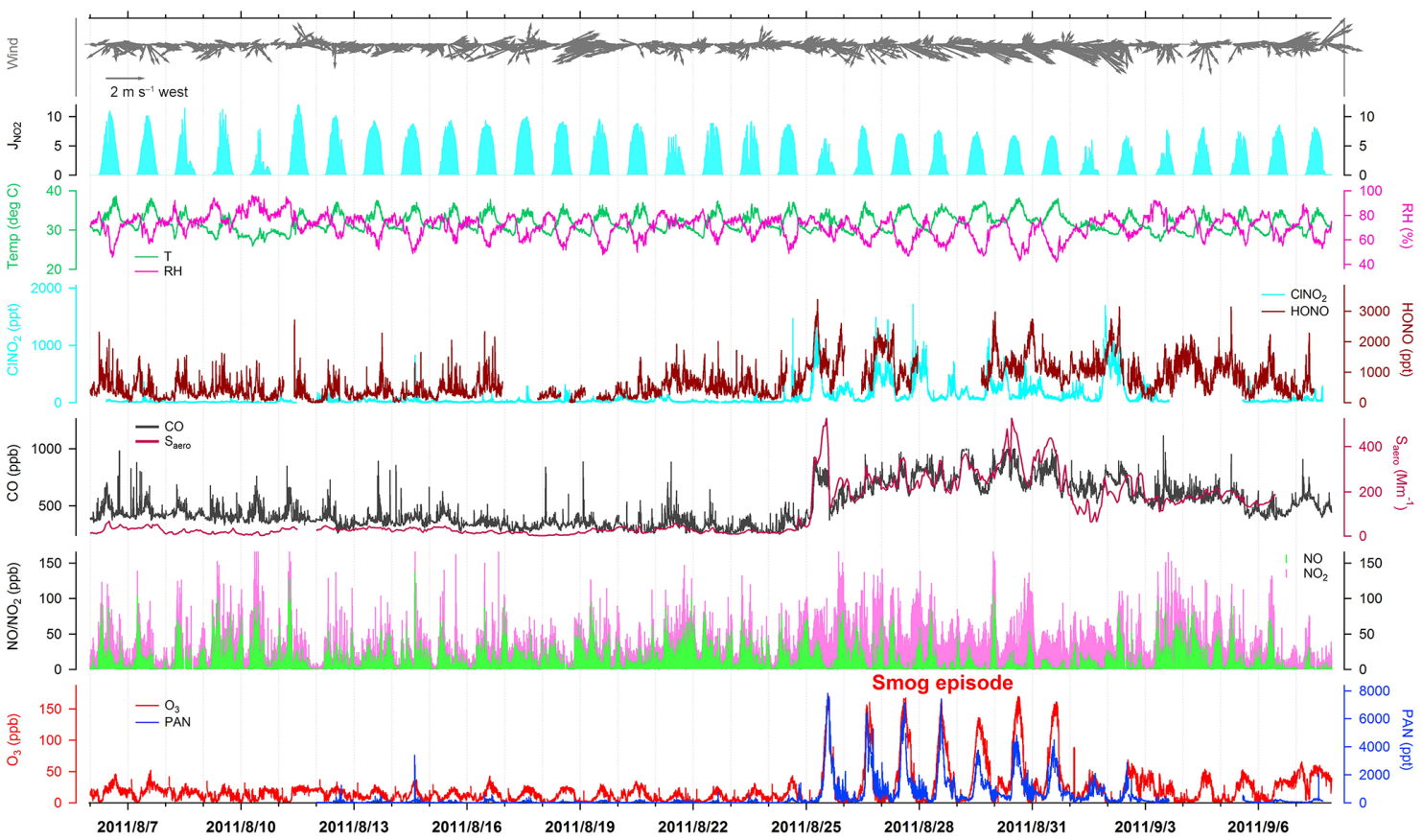

Figure 1. Time series of air pollutants and meteorological parameters observed at Tung Chung from 6 August to 7 September 2011. $S_{\text {aero }}$ stands for the scattering coefficient of $\mathrm{PM}_{2.5}$. The data gaps were mainly due to the calibration and maintenance of the instruments.

Table 1. $24 \mathrm{~h}$ average concentrations of hydrocarbons and oxygenated VOCs measured at Tung Chung on 25 and 31 August $2011^{*}$.

\begin{tabular}{lrrlrr}
\hline Species & 25 Aug & 31 Aug & Species & 25 Aug & 31 Aug \\
\hline Methane & 2.264 & 2.275 & benzene & 1008 & 569 \\
Ethane & 1192 & 525 & toluene & 9465 & 3557 \\
Propane & 2717 & 1589 & ethylbenzene & 1718 & 700 \\
$n$-Butane & 3751 & 1361 & $o$-xylene & 979 & 328 \\
$i$-Butane & 2614 & 929 & $m$-xylene & 2082 & 935 \\
$n$-Pentane & 1175 & 561 & $p$-xylene & 813 & 239 \\
$i$-Pentane & 1569 & 817 & propylbenzene & 63 & 24 \\
$n$-Hexane & 1161 & 1039 & $i$-propylbenzene & 54 & 20 \\
$n$-Heptane & 519 & 297 & $o$-ethyltoluene & 140 & 82 \\
$n$-Octane & 150 & 410 & $m$-ethyltoluene & 338 & 167 \\
$n$-Nonane & 133 & - & $p$-ethyltoluene & 143 & 113 \\
2-Methylpentane & 1123 & - & $1,2,3$-trimethylbenzene & 204 & 46 \\
3-Methylpentane & 842 & - & $1,2,4$-trimethylbenzene & 515 & 338 \\
Ethene & 1861 & 681 & $1,3,5$-trimethylbenzene & 124 & 49 \\
Propene & 537 & 482 & formaldehyde & 9890 & 8968 \\
1-butene & 196 & 136 & acetaldehyde & 4250 & 3990 \\
$i$-Butene & 224 & 282 & propanal & 940 & 670 \\
trans-2-Butene & 68 & 36 & acetone & 590 & 10670 \\
$c i s$-2-butene & 54 & 23 & butanal & 640 & 269 \\
1,3-Butadiene & 72 & 57 & pentanal & 1420 & 1596 \\
1-Pentene & 50 & 16 & hexanal & 200 & 506 \\
Isoprene & 779 & 65 & benzaldehyde & 890 & 660 \\
$\alpha$-Pinene & 92 & 48 & methyl ethyl ketone & 260 & 1027 \\
$\beta$-Pinene & 36 & 21 & acrolein & 30 & BDL \\
Ethyne & 2903 & 265 & crotonaldehyde & 30 & 510 \\
\hline & & & & & \\
& & & & &
\end{tabular}

* The units are pptv except for methane which is in ppmv. "-" indicates no data available, and "BDL" indicates below detection limit. 
culated as the sum of oxidation rates of $\mathrm{CO}$ and VOCs by the principal oxidants, namely $\mathrm{OH}, \mathrm{O}_{3}, \mathrm{NO}_{3}$ and $\mathrm{Cl}$ (Xue et al., 2015). The partitioning of the AOC among individual oxidants or VOC groups can be also assessed. The chemical budgets of $\mathrm{OH}, \mathrm{HO}_{2}$, and $\mathrm{RO}_{2}$ are quantified by grouping a huge number of relevant reactions into dozens of major production, cycling and loss routes. The principal radical sources in the polluted atmosphere generally include photolysis of $\mathrm{O}_{3}, \mathrm{HONO}, \mathrm{H}_{2} \mathrm{O}_{2}$ and OVOCs as well as reactions of $\mathrm{O}_{3}+$ VOCs, $\mathrm{NO}_{3}+$ VOCs and $\mathrm{Cl}+$ VOCs. The radical sinks mainly include the $\mathrm{RO}_{x}-\mathrm{NO}_{x}$ and $\mathrm{RO}_{x}-\mathrm{RO}_{x}$ cross reactions. Besides, a number of other minor reaction pathways were also computed to facilitate a thorough investigation of the $\mathrm{RO}_{x}$ chemistry (see Figs. 5 and 7).

The measurement data of $\mathrm{O}_{3}, \mathrm{NO}, \mathrm{NO}_{2}, \mathrm{HONO}, \mathrm{ClNO}_{2}$, $\mathrm{H}_{2} \mathrm{O}_{2}$, PAN, $\mathrm{CO}, \mathrm{C}_{1}-\mathrm{C}_{10} \mathrm{HCs}, \mathrm{C}_{1}-\mathrm{C}_{8}$ carbonyls, aerosol surface area and radius, temperature, $\mathrm{RH}$ and $J_{\mathrm{NO}_{2}}$ were averaged or interpolated to a time resolution of $10 \mathrm{~min}$ for the model constraints. For carbonyls, the diurnal profiles measured on 31 August 2011, throughout which eight $3 \mathrm{~h} \mathrm{sam-}$ ples collected were adopted and scaled to the $24 \mathrm{~h}$ average data observed on 25 August (see Fig. S4 for the measured profiles of selected carbonyls). An initial concentration of $0.5 \mathrm{ppm}$ of $\mathrm{H}_{2}$ was assumed in the model. Photolysis frequencies were calculated as a function of solar zenith angle within the model (Saunders et al., 2003) and further scaled with the measured $J_{\mathrm{NO}_{2}}$ values. The model starts from 00:00 local time (LT) and runs for a $24 \mathrm{~h}$ period. Prior to the formal calculation, the model was run for 5 days with constraints of the campaign-average data to reach steady states for the unconstrained compounds (e.g. radicals). The final outputs were extracted and subject to further analyses.

\section{Results and discussion}

\subsection{Observational overview}

The measured concentrations of major pollutants and meteorological parameters at TC are depicted in Fig. 1. During 25-31 August 2011, Hong Kong was hit by a prolonged photochemical smog episode, with concentrations of various air pollutants exceeding the ambient air quality standard (the zoomed-in figure of this episode is given in the supplement). Peak $\mathrm{O}_{3}$ mixing ratios of over $150 \mathrm{ppbv}$ were observed almost every day within the 1-week period, except for 29 August when the peak was $135 \mathrm{ppbv}$. As another indicator of photochemical smog, the concentrations of PAN were also very high with the peak values exceeding 4 ppbv every day (except for $3.7 \mathrm{ppbv}$ on 29 August). The maximum hourly values of $\mathrm{O}_{3}$ and PAN were recorded at 162 and $6.95 \mathrm{ppbv}$, respectively. Extremely high levels of $\mathrm{NO}_{x}$ (peak of $\sim 150 \mathrm{ppbv}$ ), $\mathrm{CO}$ (peak of $\sim 1000 \mathrm{ppbv}$ ) and particulate matter (as indicative of $>500 \mathrm{Mm}^{-1}$ of aerosol scattering coefficient) were also determined. Overall, inspection of observational data reveals the markedly poor air quality and serious photochemical pollution over the region during the episode.

Table 1 lists the $24 \mathrm{~h}$ average concentrations of hydrocarbons and carbonyls measured on 25 and 31 August 2011. It is clearly seen that the VOC levels, in particular for reactive aromatics and aldehydes, were also very high during the episode. On 25 August, for instance, the $24 \mathrm{~h}$ average values of toluene, summed xylenes, formaldehyde and acetaldehyde were as high as 9.47, 3.87, 9.89, and $4.25 \mathrm{ppbv}$, which were 3-30 folders higher than those measured during the non-episode period of the campaign (figures not shown). $\mathrm{HONO}$ and $\mathrm{ClNO}_{2}$, two precursors of $\mathrm{OH}$ and $\mathrm{Cl}$ radicals, were also measured. Elevated HONO (up to 23 ppbv) and moderate $\mathrm{ClNO}_{2}$ (up to $0.5-1 \mathrm{ppbv}$ ) were usually found at night, and what is more interesting is that the daytime HONO levels were also significant (over $1 \mathrm{ppbv}$ in general; see Fig. 1). Such daytime HONO levels cannot be explained by the known gas-phase source and indicates the existence of other unknown source(s) (Xu et al., 2015), yet exploring the unknown HONO sources is beyond the scope of the present study. High abundances of $\mathrm{O}_{3}, \mathrm{HONO}$ and carbonyls would definitely lead to strong production of $\mathrm{RO}_{x}$ radicals, and the abundant VOCs would facilitate efficient radical propagation (e.g. $\mathrm{OH} \rightarrow \mathrm{RO}_{2}$ ). Therefore, strong atmospheric oxidative capacity and intensive in situ photochemistry can be expected from the above analyses.

The dynamic cause of this episode was a distant tropical cyclone that introduced warm stagnant weather and facilitated accumulation of air pollutants in Hong Kong and the PRD region. The weather condition featured high temperatures $\left(30-35^{\circ} \mathrm{C}\right)$ and relatively low RH $(40-80 \%$; see Fig. S2). During the daytime, the prevailing surface winds were consistently from the northwest with relatively low wind speeds $\left(\sim 2 \mathrm{~m} \mathrm{~s}^{-1}\right)$, suggesting the transport of processed air masses from the upwind PRD region to the site. This was further confirmed by the $48 \mathrm{~h}$ backward trajectories calculated by the HYSPLIT model (Draxler and Rolph, 2016), which indicated that for most days the air masses had spent a large portion of time over the PRD region prior to arriving at TC (Fig. S3).

There was an exception on 25 August when the air flow was switching from southerly maritime air to northerly PRD regional air masses (see Fig. S3). This case is believed to be more influenced by the local air in Hong Kong, because (1) northerly winds during the daytime were somewhat weak compared to the other cases (see Fig. S2); (2) the backward trajectories also indicated less impact from the PRD region (Fig. S3); and (3) the $\mathrm{CO} / \mathrm{NO}_{y}$ ratio on that day was significantly lower than those on the following days (Fig. S5), which is consistent with the previous finding that the PRD air masses have higher $\mathrm{CO} / \mathrm{NO}_{y}$ ratios than those from Hong Kong (Wang et al., 2003). The evolution of the $\mathrm{CO} / \mathrm{NO}_{y}$ ratio clearly indicates the transition from local (25 August) to regional air masses (27-31 August) throughout the 1-week 

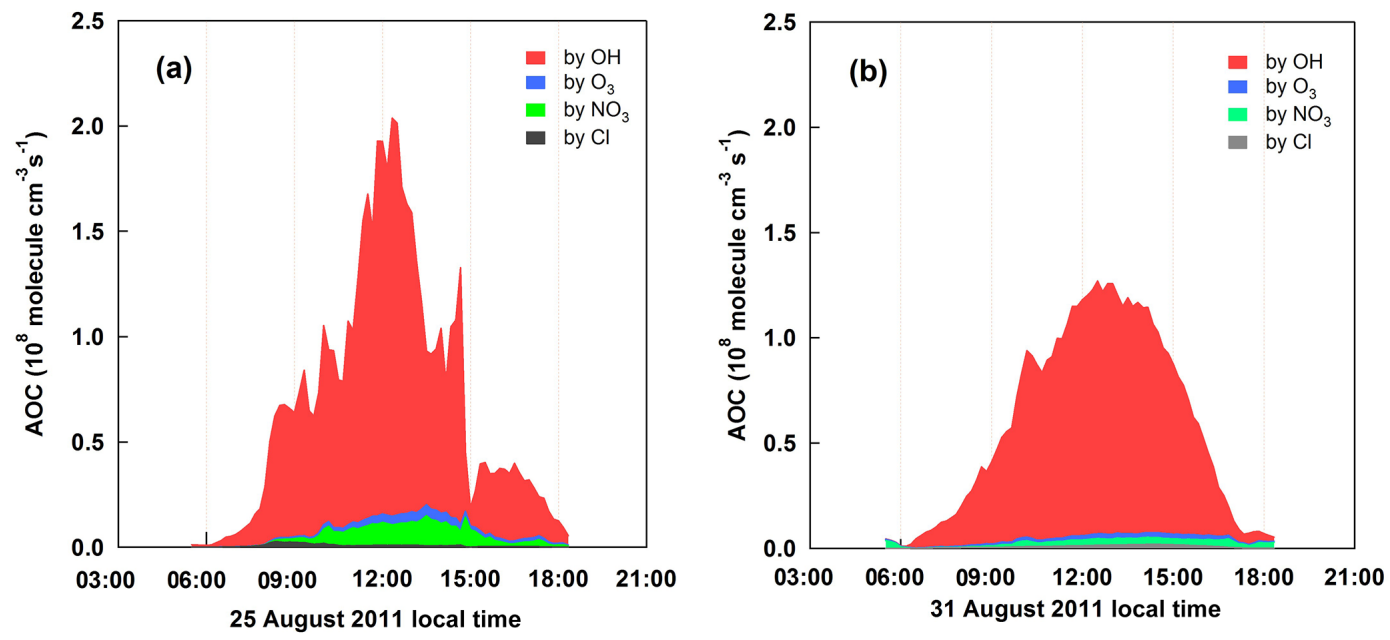

Figure 2. Daytime atmospheric oxidative capacity (AOC) and contributions of major oxidants at Tung Chung on (a) 25 August and (b) 31 August 2011.
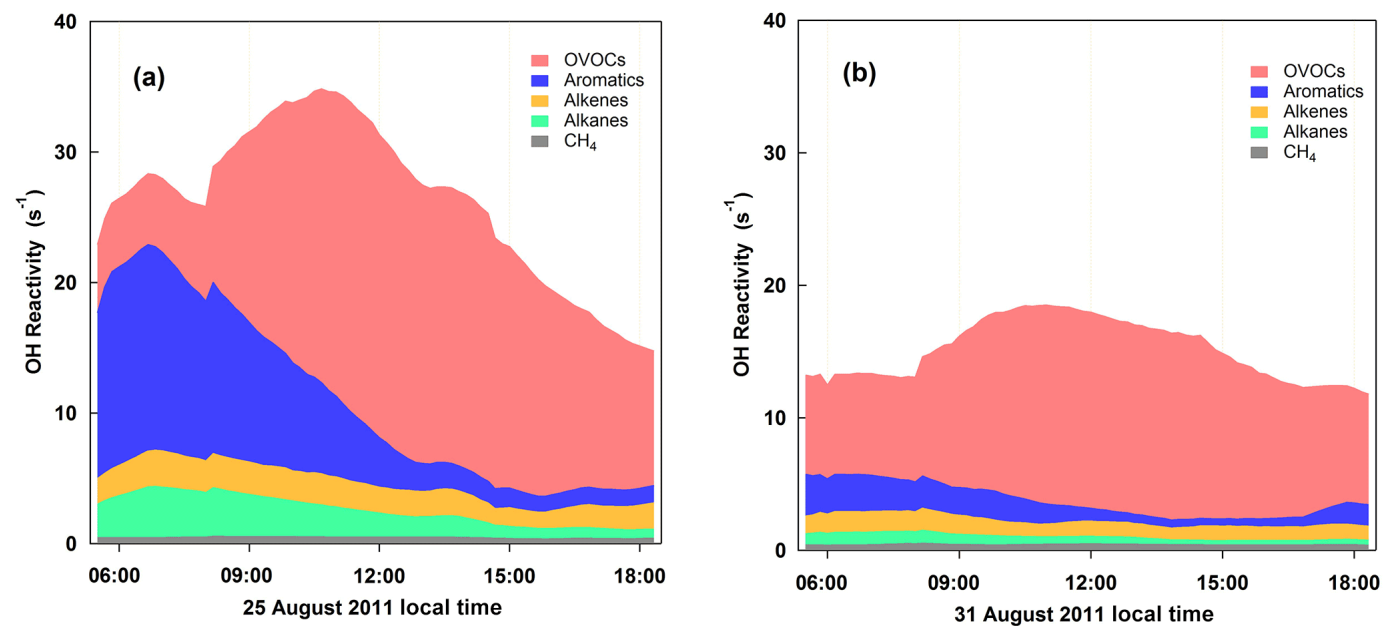

Figure 3. Partitioning of the daytime $\mathrm{OH}$ reactivity by oxidation of major VOC groups at Tung Chung on (a) 25 August and (b) 31 August 2011.

episode (Fig. S5). In the following discussion, detailed modeling analyses are conducted for the 25 and 31 August cases, which are representative of local Hong Kong and regional PRD pollution, respectively.

\subsection{Atmospheric oxidative capacity}

The strong oxidative capacity of the atmosphere during the pollution episodes was confirmed by quantifying the loss rates of $\mathrm{CO}$ and VOCs via reactions with $\mathrm{OH}, \mathrm{O}_{3}$, $\mathrm{NO}_{3}$ and $\mathrm{Cl}$, as shown in Fig. 2. The calculated AOC was up to $2.04 \times 10^{8}$ and $1.27 \times 10^{8}$ molecules $\mathrm{cm}^{-3} \mathrm{~s}^{-1}$, with daytime averages (06:00-18:00 LT) of 7.26 $\times 10^{7}$ and $6.30 \times 10^{7}$ molecules $\mathrm{cm}^{-3} \mathrm{~s}^{-1}$, on 25 and 31 August, respectively. As such, the total number of $\mathrm{CO}$ and VOC molecules depleted throughout the daytime was $3.14 \times 10^{12}$ and $2.72 \times 10^{12}$ per $\mathrm{cm}^{-3}$ of air for both cases. Such levels of AOC at TC are much higher than those determined from a rural site in Germany (Geyer et al., 2001), but a bit lower than that assessed from a polluted area in Santiago, Chile (Elshorbany et al., 2009).

$\mathrm{OH}$ was, as expected, the predominant oxidant accounting for 89 and $93 \%$ of the AOC on 25 and 31 August, respectively. $\mathrm{NO}_{3}$ was the second important oxidant with contributions of 7 and $3 \%$ for both cases. In particular, $\mathrm{NO}_{3}$ contributed to $43 \%$ of the AOC at 15:00 LT on 25 August under a weak solar radiation condition. The major fuels for $\mathrm{NO}_{3} \mathrm{ox}-$ idation were OVOCs (i.e. 77-90\%) and alkenes (10-23\%). In comparison, $\mathrm{O}_{3}$ and $\mathrm{Cl}$ (produced from $\mathrm{ClNO}_{2}$ photolysis) had minor contributions due to the relatively lower abundances of alkenes and $\mathrm{Cl}$ radicals (i.e. the modelled peak value of $\mathrm{Cl}$ was $\sim 1 \times 10^{4}$ atoms $\mathrm{cm}^{-3}$ ). Overall, the $\mathrm{OH}$ - 
dominated AOC at TC is in line with the previous studies at other urban locales (Elshorbany et al., 2009; Bannan et al., 2015), and the present analysis suggests that the $\mathrm{NO}_{3}$ radical may play an important role in the daytime oxidation under certain conditions (see a detailed evaluation in Sect. 3.4).

We further assessed the loss rates of major VOC groups due to $\mathrm{OH}$ oxidation, from which the partitioning of $\mathrm{OH}$ reactivity among different VOCs can be elucidated. The results are presented in Fig. 3. OVOCs clearly dominate the $\mathrm{OH}$ reactivity with daytime average contributions of 60 and $75 \%$ and with maximums in the afternoon of over $80 \%$ for both cases. Aromatics are the second largest contributor comprising on average 22 and $10 \%$ of the daytime $\mathrm{OH}$ reactivity. For the Hong Kong local case on 25 August, especially, aromatics made up the majority (i.e. 40-60\%) of the $\mathrm{OH}$ reactivity in the early morning period when there were much fresher air masses. In comparison, alkenes and alkanes only accounted for a small fraction $(8-10 \%)$ of the $\mathrm{OH}$ reactivity at $\mathrm{TC}$. These results are in fair agreement with the previous studies of Lou et al. (2010) and Whalley et al. (2016), which indicated the dominance of secondary OVOCs in the observed $\mathrm{OH}$ reactivity in the $\mathrm{PRD}$ region and central London.

As shown above, the partitioning of principal oxidants and $\mathrm{OH}$ reactivity is quite similar for both cases. In comparison with the regional case on 31 August 2011, nonetheless, the Hong Kong local case (i.e. 25 August 2011) showed higher AOC levels and more contribution from aromatic VOCs to the $\mathrm{OH}$ reactivity. Such difference should be due to the fresher air masses and hence more reactive VOC species during the local case. In the following section, a detailed budget analysis of the radical initiation, recycling and termination processes is presented.

\subsection{RO $\mathrm{R}_{x}$ budget analysis}

\subsubsection{The Hong Kong local case}

Figure 4 presents the primary daytime sources of $\mathrm{OH}, \mathrm{HO}_{2}$ and $\mathrm{RO}_{2}$ at TC on 25 August 2011, and the detailed daytime $\mathrm{RO}_{x}$ budget is schematically illustrated in Fig. 5. HONO photolysis is not only the predominant source of $\mathrm{OH}$ in the early morning but also a major source throughout the daytime. Photolysis of $\mathrm{O}_{3}$ becomes an important $\mathrm{OH}$ source at midday, the strength of which is comparable to that of HONO photolysis. In terms of the daytime average (06:0018:00 LT), HONO photolysis is the dominant $\mathrm{OH}$ source with an average $\mathrm{OH}$ production rate of $1.5 \mathrm{ppbv}^{-1}$, followed by $\mathrm{O}_{3}$ photolysis $\left(0.9 \mathrm{ppbv} \mathrm{h}^{-1}\right)$. In addition, ozonolysis reactions of unsaturated VOCs are another considerable $\mathrm{OH}$ source with a mean production rate of $0.2 \mathrm{ppbvh}^{-1}$, whilst other sources (e.g. photolysis of $\mathrm{H}_{2} \mathrm{O}_{2}, \mathrm{HNO}_{3}$ and OVOCs) are generally negligible.

For $\mathrm{HO}_{2}$, the most important source is the photolysis of OVOCs (including not only the measured carbonyls but also the oxidation products generated within the model), with
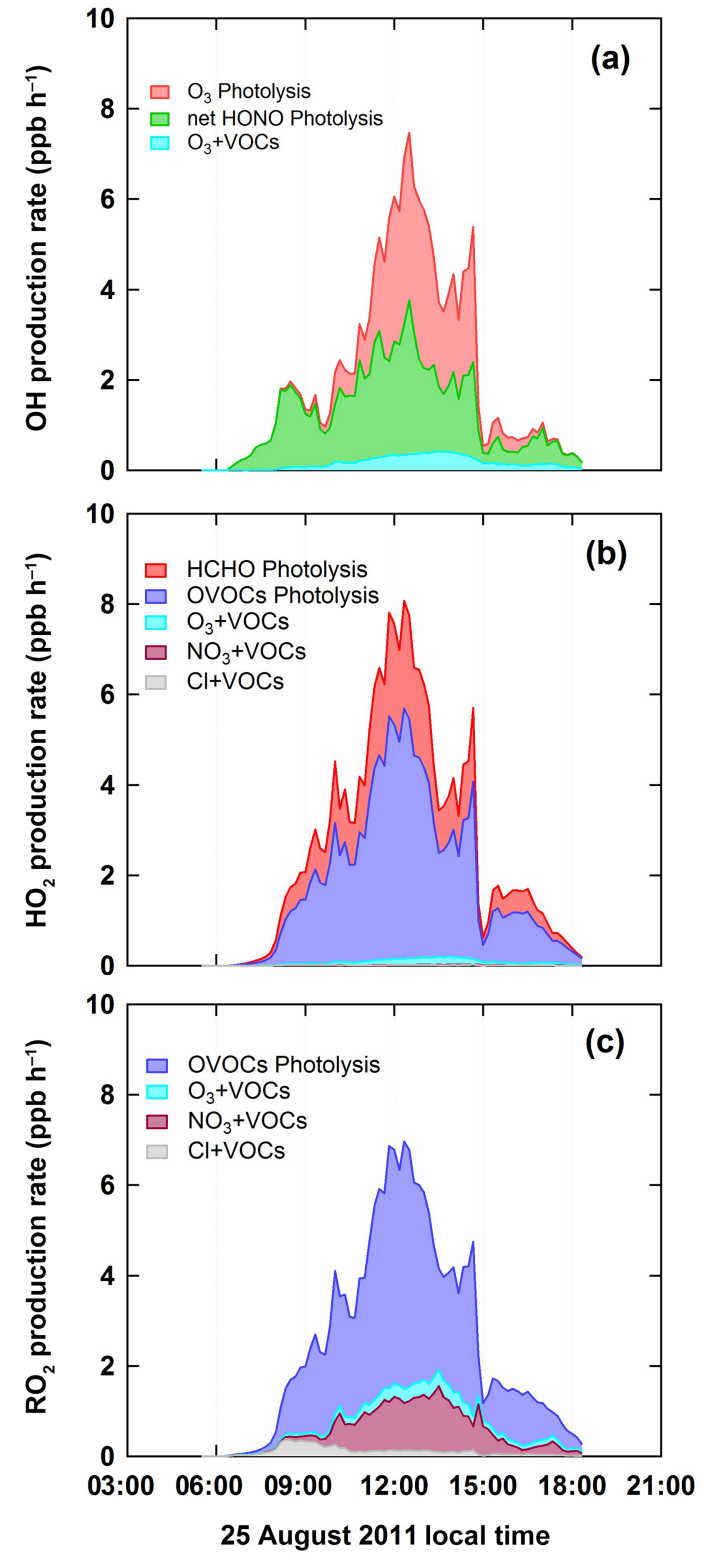

Figure 4. Primary daytime sources of (a) $\mathrm{OH}$, (b) $\mathrm{HO}_{2}$ and (c) $\mathrm{RO}_{2}$ radicals at Tung Chung on 25 August 2011. The term "net HONO photolysis" represents the contribution of net HONO (i.e. subtracting the formation rate of $\mathrm{HONO}$ from $\mathrm{NO}+\mathrm{OH}=\mathrm{HONO}$ ).

a daytime average production rate of $2.7 \mathrm{ppbv} \mathrm{h}^{-1}$. Specifically, photolysis of formaldehyde produces $\mathrm{HO}_{2}$ at a rate of $0.8 \mathrm{ppbv} \mathrm{h}^{-1}$, while the remaining majority $\left(1.9 \mathrm{ppbv} \mathrm{h}^{-1}\right)$ is from the photolysis of the other OVOCs. Such source strength of OVOC photolysis was comparable to those determined in the metropolitan areas of Beijing (Liu et al., 2012) and Mexico City (Volkamer et al., 2010). In addition, another source that needs to be considered is reactions of $\mathrm{O}_{3}$ with unsaturated VOCs, which produce $\mathrm{HO}_{2}$ at $0.1 \mathrm{ppbvh}^{-1}$ on average during the daytime. 
For $\mathrm{RO}_{2}$, photolysis of OVOCs presents the dominant source with a daytime mean production rate of $1.9 \mathrm{ppbv} \mathrm{h}^{-1}$. The $\mathrm{NO}_{3}$ oxidation of VOCs is the second-most significant $\mathrm{RO}_{2}$ source at TC, contributing $0.5 \mathrm{ppbv} \mathrm{h}^{-1}$ of daytime $\mathrm{RO}_{2}$ production. This result suggests that $\mathrm{NO}_{3}$ may play an important role in the daytime chemistry of the polluted atmosphere, and is different from most results obtained elsewhere which have indicated the negligible role of $\mathrm{NO}_{3}$ in the daytime photochemistry (Stone et al., 2012; and references therein; a detailed analysis is presented in Sect. 3.4). Ozonolysis reactions of VOCs also contribute moderately to the daytime $\mathrm{RO}_{2}$ production $\left(0.2 \mathrm{ppbvh}^{-1}\right)$. Furthermore, oxidation of VOCs by the chlorine atoms, which are produced by photolysis of the nocturnally formed $\mathrm{ClNO}_{2}$, is another $\mathrm{RO}_{2}$ source $\left(0.1 \mathrm{ppbv} \mathrm{h}^{-1}\right)$, particularly in the early morning period (with a maximum of $0.4 \mathrm{ppbv} \mathrm{h}^{-1}$ ).

From the $\mathrm{RO}_{x}$ perspective, the primary radical production in Hong Kong is dominated by photolysis of OVOCs (except for $\mathrm{HCHO}$ ), followed by photolysis of $\mathrm{HONO}, \mathrm{O}_{3}$ and $\mathrm{HCHO}$, and reactions of $\mathrm{O}_{3}+\mathrm{VOCs}$ and $\mathrm{NO}_{3}+$ VOCs. Comparison of Hong Kong with other metropolitan areas clearly reveals the heterogeneity in radical chemistry in different urban environments. For example, the dominant radical sources are $\mathrm{O}_{3}$ photolysis in Nashville (Martinez et al., 2003), HONO photolysis in New York City (Ren et al., 2003), Paris (Michoud et al., 2012) and Santiago (Elshorbany et al., 2009), HCHO photolysis in Milan (Alicke et al., 2002), and OVOC photolysis in Hong Kong, Beijing (Liu et al., 2012), Mexico City (Volkamer et al., 2010), Birmingham (summer case; Emmerson et al., 2005) and Chelmsford near London (Emmerson et al., 2007). It is worth noting that HONO was not measured at Birmingham and Chelmsford but only simulated by a chemical box model, and thus the contributions of HONO photolysis were likely underestimated. The above analysis highlights the variability of the initiation mode of atmospheric photochemistry, which ultimately drives the formation of ozone and secondary aerosols in urban atmospheres.

Efficient recycling of radicals can be also illustrated in Fig. 5. Oxidation of $\mathrm{CO}$ and VOCs by $\mathrm{OH}$ produces $\mathrm{HO}_{2}$ and $\mathrm{RO}_{2}$ with daytime average rates of 3.3 and $8.0 \mathrm{ppbv} \mathrm{h}^{-1}$, respectively. Reactions of $\mathrm{RO}_{2}+\mathrm{NO}$ and $\mathrm{HO}_{2}+\mathrm{NO}$ in turn result in strong production of $\mathrm{RO}\left(9.0 \mathrm{ppbvh}^{-1}\right)$ and $\mathrm{OH}$ $\left(12.5 \mathrm{ppbv} \mathrm{h}^{-1}\right)$, with $\mathrm{O}_{3}$ formed as a by-product. It is evident that these recycling processes dominate the total production of $\mathrm{OH}, \mathrm{HO}_{2}$ and $\mathrm{RO}_{2}$ radicals. It is common that the radical propagation is efficient and amplifies the effect of the newly produced radicals in the polluted atmospheres with the co-existence of abundant $\mathrm{NO}_{x}$ and VOCs (Elshorbany et al., 2009; Liu et al., 2012). As to the termination processes, the $\mathrm{RO}_{x}$ radical sink is clearly dominated by their reactions with $\mathrm{NO}_{x}$. Specifically, reactions of $\mathrm{OH}+\mathrm{NO}_{2}$ and $\mathrm{RO}_{2}+\mathrm{NO}_{2}$, forming $\mathrm{HNO}_{3}$ and organic nitrates, contributed approximately 2.8 and $2.5 \mathrm{ppbvh}^{-1}$ of the radical loss on daytime average at TC. This is in line with the understanding

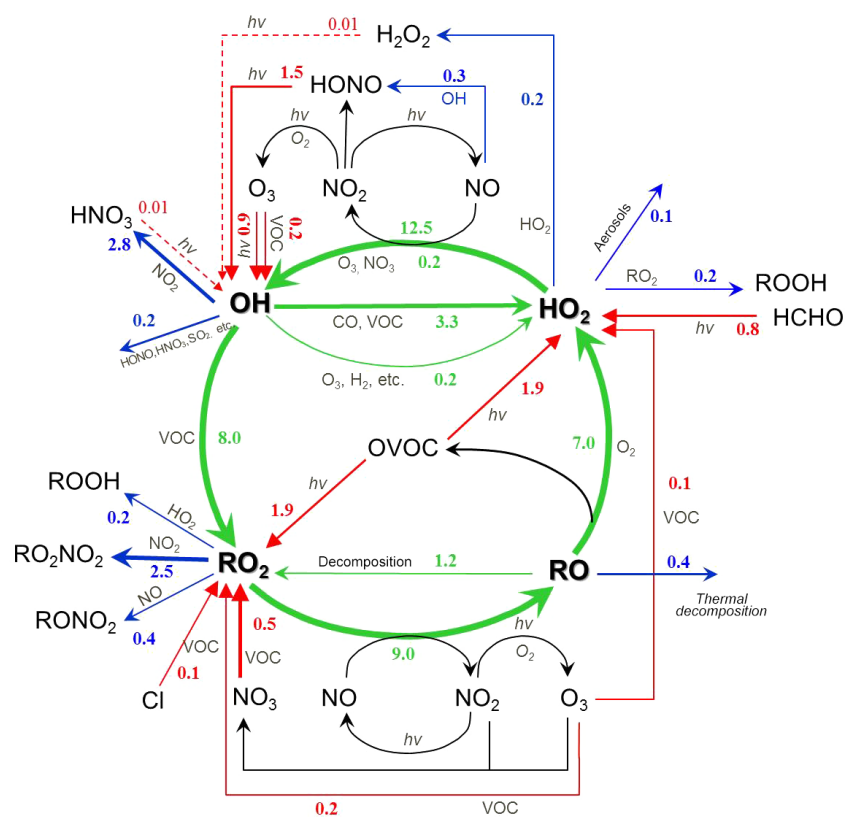

Figure 5. Daytime average $\mathrm{RO}_{x}$ budget at Tung Chung on $25 \mathrm{Au}$ gust 2011. The unit is $\mathrm{ppbh}^{-1}$. The red, blue and green lines indicate the production, destruction and recycling pathways of radicals, respectively.

that reactions with $\mathrm{NO}_{x}$ usually dominate the radical sink in high- $\mathrm{NO}_{x}$ environments.

\subsubsection{The PRD regional case}

The detailed radical budget for the regional case on $31 \mathrm{Au}-$ gust 2011 is illustrated in Figs. 6 and 7. Overall, the chemical budget of $\mathrm{RO}_{x}$ radicals was essentially the same as that of the Hong Kong local case. Specifically, the most significant primary source is photolysis of OVOCs except for HCHO, which produces both $\mathrm{HO}_{2}$ and $\mathrm{RO}_{2}$ equally at a daytime average rate of $1.3 \mathrm{ppbvh}^{-1}$. The other important radical sources include photolysis of HONO $\left(1.7 \mathrm{ppbvh}^{-1}\right.$ as $\left.\mathrm{OH}\right)$, $\mathrm{O}_{3}\left(1.5 \mathrm{ppbv} \mathrm{h}^{-1}\right.$ as $\left.\mathrm{OH}\right)$ and $\mathrm{HCHO}\left(1.2 \mathrm{ppbv} \mathrm{h}^{-1}\right.$ as $\left.\mathrm{HO}_{2}\right)$, ozonolysis reactions of unsaturated VOCs $\left(0.3 \mathrm{ppbv} \mathrm{h}^{-1}\right.$ for the sum of $\left.\mathrm{RO}_{x}\right)$, and reactions of $\mathrm{NO}_{3}+\mathrm{VOCs}\left(0.2 \mathrm{ppbv} \mathrm{h}^{-1}\right.$ as $\left.\mathrm{RO}_{2}\right)$ and $\mathrm{Cl}+\mathrm{VOCs}\left(0.1 \mathrm{ppbvh}^{-1}\right.$ as $\left.\mathrm{RO}_{2}\right)$. For the termination processes, reactions of $\mathrm{OH}+\mathrm{NO}_{2}$ and $\mathrm{RO}_{2}+\mathrm{NO}_{2}$ present the major radical loss pathways, with daytime average rates of 3.5 and $1.5 \mathrm{ppbv} \mathrm{h}^{-1}$, respectively.

Despite the abovementioned general similarity, two aspects are noteworthy about the difference between the two cases. First, the primary radical source strength was significantly higher on 25 August than 31 August, suggesting the stronger oxidation capacity of the atmosphere during the local case. Second, the source strengths of photolysis of $\mathrm{HONO}, \mathrm{O}_{3}$ and $\mathrm{HCHO}$ were higher on 31 August than 25 August, whilst the sources of OVOCs photolysis, $\mathrm{O}_{3}+$ VOCs and $\mathrm{NO}_{3}+$ VOCs showed an opposite picture. Such differ- 

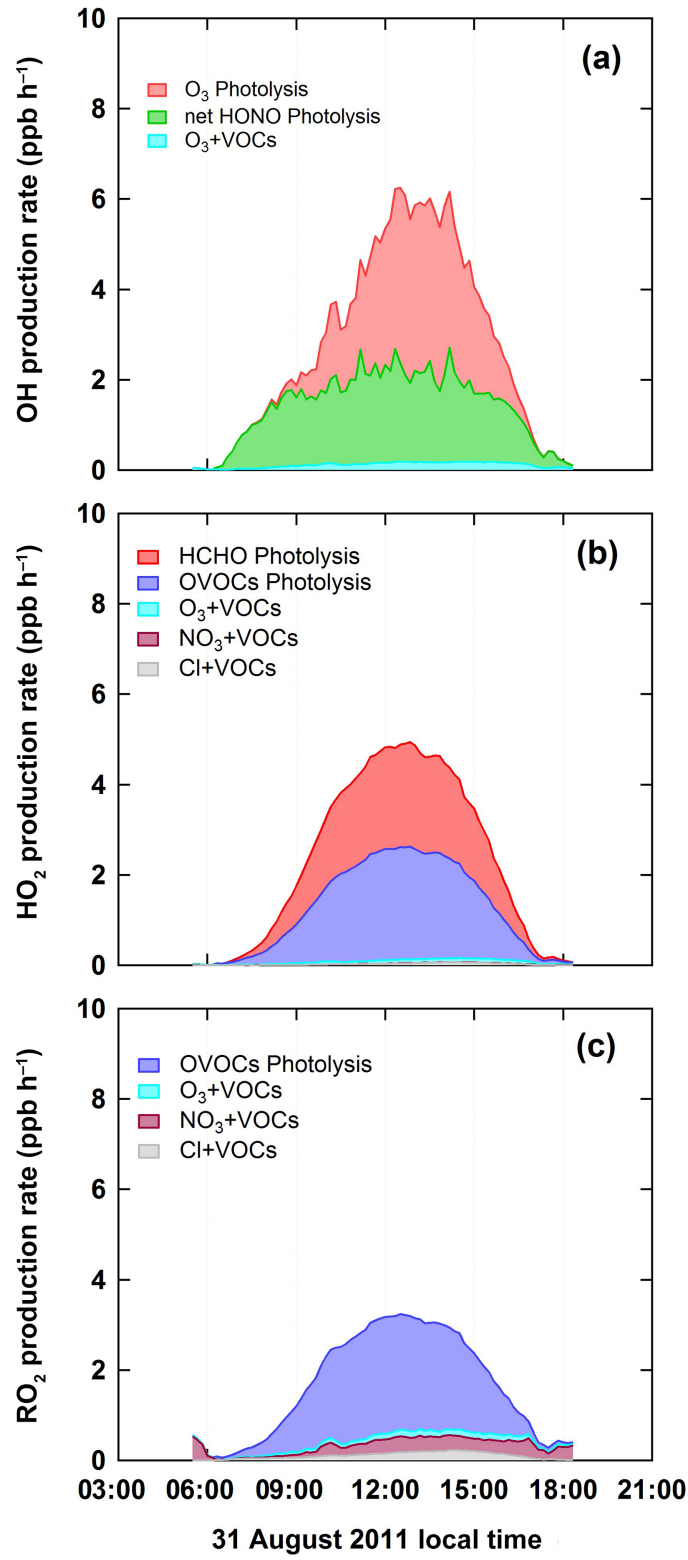

Figure 6. The same as Fig. 4 but for the case of 31 August 2011.

ence in the partitioning of radical sources between both cases should be ascribed to the higher VOC levels (with more fresh emissions) and weaker solar radiation (possibly attenuated by the high aerosol loading; see Sect. 3.4) on 25 August.

\subsection{Evidence of daytime $\mathrm{NO}_{3}$ chemistry}

The $\mathrm{NO}_{3}$ radical can initiate the oxidation of VOCs and lead to formation of $\mathrm{RO}_{2}$ and nitrogen-containing organic aerosols (Rollins et al., 2012; Saunders et al., 2003). These processes are usually considered to mainly occur at night and be negligible during the daytime due to the fast photolysis of $\mathrm{NO}_{3}$. In the present study, we observed an interesting case that provided evidence of the operation of daytime $\mathrm{NO}_{3}-$

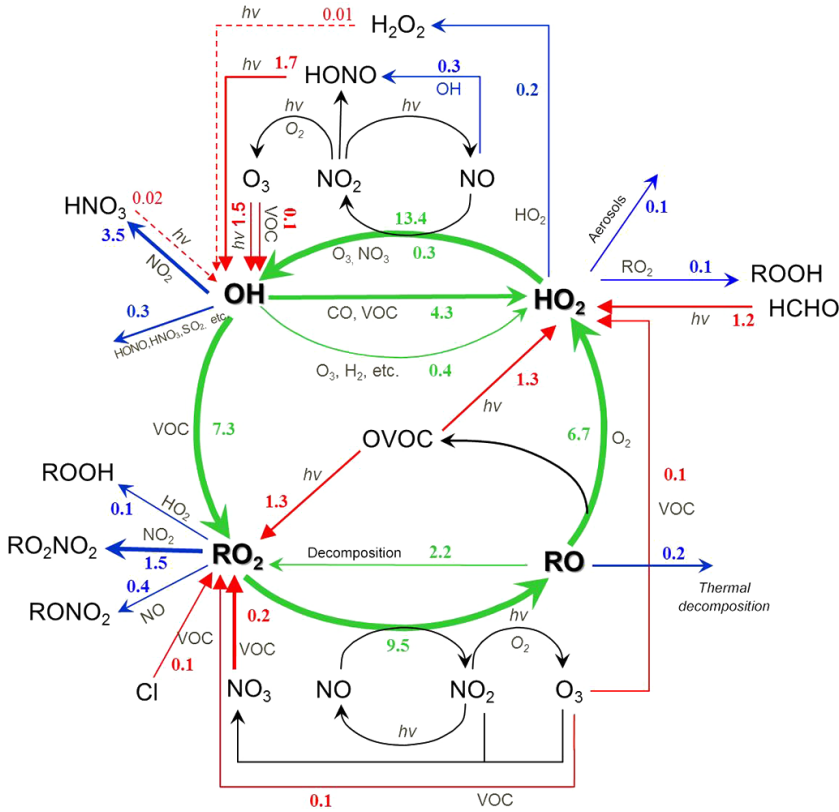

Figure 7. The same as Fig. 5 but for the case of 31 August 2011.

initiated chemistry. The detailed measurement data of chemical and meteorological parameters in this case (i.e. 25 August 2011) are depicted in Fig. 8. During this episode, the air was characterized by high concentrations of $\mathrm{O}_{3}$ (up to $170 \mathrm{ppbv}$ ), $\mathrm{NO}_{2}(\sim 25 \mathrm{ppbv}$ as the afternoon average) and VOCs (see Table 1). Meanwhile, the solar irradiation arriving at the surface was weaker than other days, as evidenced by the relatively lower values of $J_{\mathrm{NO}_{2}}$ (with a peak of $6.0 \times 10^{-3} \mathrm{~s}^{-1}$ ) compared to clear days with $\sim 10 \times 10^{-3} \mathrm{~s}^{-1}$ (see Fig. 1). The ambient relative humidity $(\mathrm{RH})$ in the afternoon was in the range of $60-70 \%$, implying that there was little cloud on the site, whilst the aerosol scattering coefficient was very high (up to $525 \mathrm{Mm}^{-1}$; compared to $28 \pm 12 \mathrm{Mm}^{-1}$ on clear days). Hence, the attenuated solar radiation is possibly attributed to the abundant aerosol loadings. Under such conditions, the model produced an afternoon peak of $\mathrm{NO}_{3}$ of $\sim 7$ pptv at 13:30-15:00 LT (except for the maximum of 11.3 pptv at 14:50 LT that was coincident with an extremely low solar radiation condition).

To further understand the causes and impacts of the daytime $\mathrm{NO}_{3}$ chemistry, a detailed budget analysis was conducted with the OBM-AOCP model. The midday average (09:00-15:00 LT) production and destruction rates of $\mathrm{NO}_{3}$ from the individual reaction pathways are documented in Fig. 9. The co-existence of high concentrations of $\mathrm{O}_{3}$ and $\mathrm{NO}_{2}$ resulted in a very strong $\mathrm{NO}_{3}$ production with an average strength of $11.0 \mathrm{ppbh}^{-1}$. Given its high reactivity, $\mathrm{NO}_{3}$ once formed, can be readily photolysed as well as react with $\mathrm{NO}$ and VOCs. For this case, about $80 \%$ (i.e. $8.8 \mathrm{ppb} \mathrm{h}^{-1}$ ) of $\mathrm{NO}_{3}$ reacted with $\mathrm{NO}$ to convert back to $\mathrm{NO}_{2}$. Due to the weak solar radiation, photolysis only accounted for 


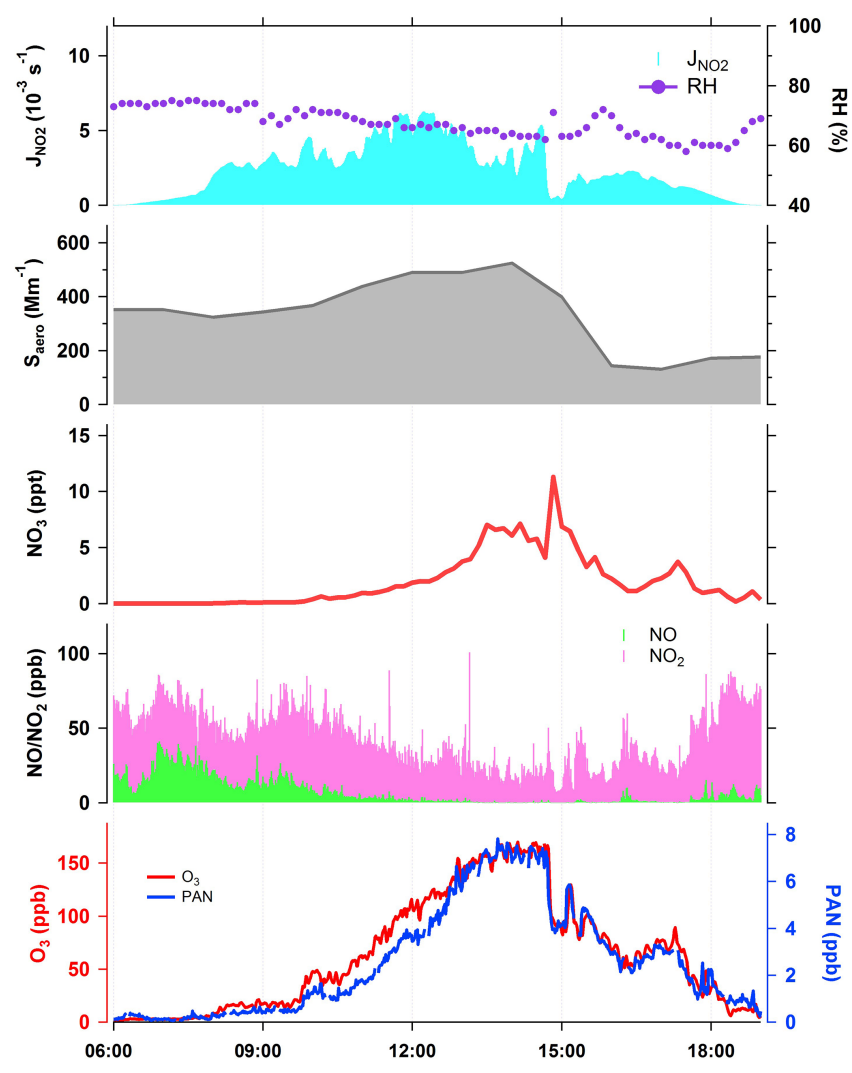

Figure 8. Time series of chemical and meteorological parameters observed at Tung Chung on 25 August 2011.

$6.2 \%$ (or $0.7 \mathrm{ppbh}^{-1}$ ) of the $\mathrm{NO}_{3}$ loss. In comparison, reactions of $\mathrm{NO}_{3}$ with VOCs contributed $11.7 \%$ (or $1.3 \mathrm{ppb} \mathrm{h}^{-1}$ ) to the total loss at midday. During this episode, therefore, $\mathrm{NO}_{3}$ appeared to be the second-most important oxidant (see Sect. 3.2) and the reactions of $\mathrm{NO}_{3}$ with VOCs presented a considerable $\mathrm{RO}_{2}$ source during the daytime (Sect. 3.3). In addition, the $\mathrm{NO}_{3}$-initiated degradation of VOCs could also lead to formation of secondary organic nitrate aerosols, but was not simulated in the present study.

The above analysis indicates the possible importance of $\mathrm{NO}_{3}$-initiated oxidation in the daytime atmospheric photochemistry under specific conditions. This analysis is solely derived from an observation-based modeling study of a unique pollution case in Hong Kong. Nevertheless, we hypothesize that it may also take place in other polluted urban atmospheres, especially in the large cities of China. It is known that eastern China now suffers from widespread and severe photochemical smog during the summer, which features elevated concentrations of $\mathrm{O}_{3}, \mathrm{NO}_{x}$, VOCs, and fine particulate matter (Xue et al., 2014a). The intense air pollution usually induces "smoldering" weather with poor visibility and hence attenuated solar irradiation (Ding et al., 2013). All these unfavourable conditions would facilitate the operation of daytime $\mathrm{NO}_{3}$ chemistry as found in Hong Kong in

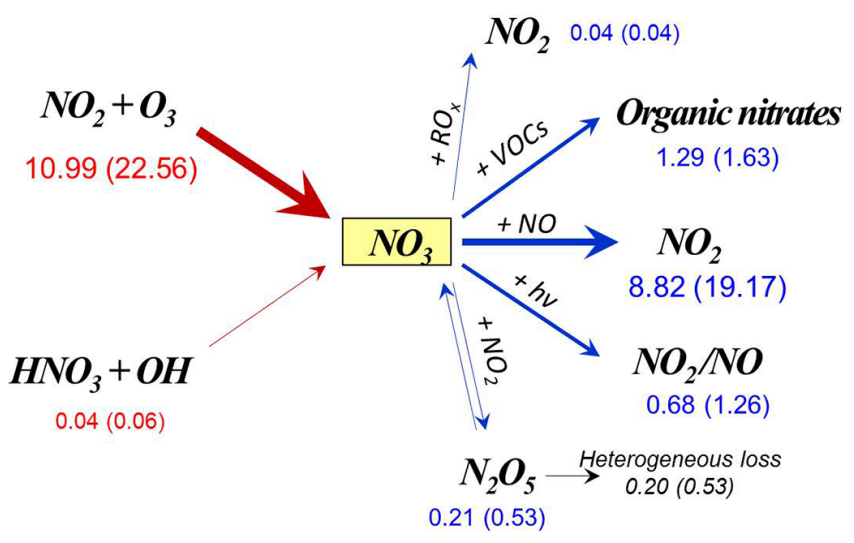

Figure 9. Midday average (09:00-15:00 LT) budget of the $\mathrm{NO}_{3}$ radical at Tung Chung on 25 August 2011. The units are $\mathrm{ppb} \mathrm{h}^{-1}$. Peak values are also given in parentheses.

the present study. Further studies are required to verify this phenomenon in other polluted environments and quantify its contributions to the formation of ozone and secondary organic aerosols.

\section{Conclusions}

The detailed atmospheric photochemistry during a severe smog episode in Hong Kong is analysed. A strong oxidative capacity of the atmosphere is found and ascribed to $\mathrm{OH}$ and to a lesser extent $\mathrm{NO}_{3}$. Elevated concentrations of $\mathrm{O}_{3}$, $\mathrm{NO}_{2}$, HONO and VOCs were concurrently observed, which resulted in strong production of $\mathrm{RO}_{x}$ and $\mathrm{NO}_{3}$ as well as efficient radical recycling. Photolysis of OVOCs other than $\mathrm{HCHO}$ was found to be the dominant primary $\mathrm{RO}_{x}$ source, followed by photolysis of $\mathrm{HONO}, \mathrm{O}_{3}$ and $\mathrm{HCHO}$, and reactions of $\mathrm{O}_{3}+\mathrm{VOCs}$ and $\mathrm{NO}_{3}+$ VOCs. Higher AOC levels and stronger primary production of radicals were determined during the Hong Kong local case compared to the PRD regional case. Although the primary radical sources were essentially the same, photolysis of OVOCs (except for $\mathrm{HCHO}$ ) and reactions of $\mathrm{O}_{3}+\mathrm{VOCs}$ and $\mathrm{NO}_{3}+\mathrm{VOCs}$ were stronger for the Hong Kong local case, which was ascribed to the higher VOC levels. In comparison, the source strengths of photolysis of $\mathrm{HONO}, \mathrm{O}_{3}$ and $\mathrm{HCHO}$ were higher during the regional case.

On 25 August 2011, a unique case when heavy air pollution attenuated the solar irradiation reaching the surface in Hong Kong, $\mathrm{NO}_{3}$ was identified as an important oxidant in the daytime chemistry. VOC oxidation by $\mathrm{NO}_{3}$ represented the second largest source of $\mathrm{RO}_{2}$, with a daytime average production rate of $0.5 \mathrm{ppbvh}^{-1}$. The $\mathrm{NO}_{3}$-initiated degradation of VOCs would enhance the formation of $\mathrm{O}_{3}$ and nitrogen-containing organic aerosols. This study indicates the potential operation of the daytime $\mathrm{NO}_{3}$ chemistry in polluted urban atmospheres characterized by the co-existence of abundant $\mathrm{O}_{3}, \mathrm{NO}_{2}$, VOCs and particles. Further studies, es- 
pecially direct observations of the $\mathrm{NO}_{3}$ radical, are required to verify this interesting phenomenon in other environments and to evaluate its contribution to the $\mathrm{O}_{3}$ and secondary organic aerosol formation.

\section{Data availability}

The underlying research data can be accessed upon contact with the corresponding author (L. K. Xue; xuelikun@sdu.edu.cn).

\section{The Supplement related to this article is available online at doi:10.5194/acp-16-9891-2016-supplement.}

Acknowledgements. The authors appreciate Steven Poon, Yee Jun Tham, Shengzhen Zhou, Wei Nie and Jia Guo for their contributions to the field study; the University of Leeds for providing the Master Chemical Mechanism; and the NOAA Air Resources Laboratory for providing the web-based HYSPLIT model. We thank the two anonymous referees for their helpful comments to improve the quality of our original manuscript. The field observations were funded by the Environment and Conservation Fund of Hong Kong (project no.: 7/2009), and the data analyses were supported by the National Natural Science Foundation of China (project no.: 41505111) and Qilu Youth Talent Programme of Shandong University.

Disclaimer. The opinions expressed in this paper are those of the authors and do not necessarily reflect the views or policies of the Government of the Hong Kong Special Administrative Region, nor does mention of trade names or commercial products constitute an endorsement or recommendation of their use.

Edited by: D. Heard

Reviewed by: two anonymous referees

\section{References}

Alicke, B., Platt, U., and Stutz, J.: Impact of nitrous acid photolysis on the total hydroxyl radical budget during the Limitation of Oxidant Production/Pianura Padana Produzione di Ozono study in Milan, J. Geophys. Res.-Atmos., 107, 8196, doi:10.1029/2000JD000075, 2002.

Bannan, T. J., Booth, A. M., Bacak, A, Muller, J. B. A., Leather, K. E., Breton, M. L., Jones, B., Young, D., Coe, H., Allan, J., Visser, S., Slowik, J. G., Furger, M., Prévôt, A. S. H., Lee, J., Dunmore, R. E., Hopkins, J. R., Hamilton, J. F., Lewis, A. C., Whalley, L. K., Sharp, T., Stone, D., Heard, D. E., Fleming, Z. L., Leigh, R., Shallcross, D. E., and Percival, C. J.: The first UK measurements of nitryl chloride using a chemical ionization mass spectrometer in central London in the summer of 2012, and an investigation of the role of $\mathrm{Cl}$ atom oxidation, J. Geophys. Res.-Atmos., 120, 5638-5657, 2015.
Ding, A. J., Fu, C. B., Yang, X. Q., Sun, J. N., Petäjä, T., Kerminen, V.-M., Wang, T., Xie, Y., Herrmann, E., Zheng, L. F., Nie, W., Liu, Q., Wei, X. L., and Kulmala, M.: Intense atmospheric pollution modifies weather: a case of mixed biomass burning with fossil fuel combustion pollution in eastern China, Atmos. Chem. Phys., 13, 10545-10554, doi:10.5194/acp-13-10545-2013, 2013.

Draxler, R. R. and Rolph, G. D.: HYSPLIT (HYbrid Single-Particle Lagrangian Integrated Trajectory) Model access via NOAA ARL READY Website, http://ready.arl.noaa.gov/HYSPLIT.php (last access: 26 May 2016), NOAA Air Resources Laboratory, Silver Spring, MD, 2016.

Dusanter, S., Vimal, D., Stevens, P. S., Volkamer, R., Molina, L. T., Baker, A., Meinardi, S., Blake, D., Sheehy, P., Merten, A., Zhang, R., Zheng, J., Fortner, E. C., Junkermann, W., Dubey, M., Rahn, T., Eichinger, B., Lewandowski, P., Prueger, J., and Holder, H.: Measurements of $\mathrm{OH}$ and $\mathrm{HO}_{2}$ concentrations during the MCMA-2006 field campaign - Part 2: Model comparison and radical budget, Atmos. Chem. Phys., 9, 6655-6675, doi:10.5194/acp-9-6655-2009, 2009.

Elshorbany, Y. F., Kurtenbach, R., Wiesen, P., Lissi, E., Rubio, M., Villena, G., Gramsch, E., Rickard, A. R., Pilling, M. J., and Kleffmann, J.: Oxidation capacity of the city air of Santiago, Chile, Atmos. Chem. Phys., 9, 2257-2273, doi:10.5194/acp-92257-2009, 2009.

Emmerson, K. M., Carslaw, N., and Pilling, M. J.: Urban atmospheric chemistry during the PUMA campaign 2: Radical budgets for $\mathrm{OH}, \mathrm{HO}_{2}$ and $\mathrm{RO}_{2}$, J. Atmos. Chem., 52, 165-183, 2005.

Emmerson, K. M., Carslaw, N., Carslaw, D. C., Lee, J. D., McFiggans, G., Bloss, W. J., Gravestock, T., Heard, D. E., Hopkins, J., Ingham, T., Pilling, M. J., Smith, S. C., Jacob, M., and Monks, P. S.: Free radical modelling studies during the UK TORCH Campaign in Summer 2003, Atmos. Chem. Phys., 7, 167-181, doi:10.5194/acp-7-167-2007, 2007.

Gao, J., Wang, T., Zhou, X. H., Wu, W. S., and Wang, W. X.: Measurement of aerosol number size distributions in the Yangtze River delta in China: Formation and growth of particles under polluted conditions, Atmos. Environ., 43, 829-836, 2009.

Geyer, A., Alicke, B., Konrad, S., Schmitz, T., Stutz, J., and Platt, U.: Chemistry and oxidation capacity of the nitrate radical in the continental boundary layer near Berlin, J. Geophys. Res.-Atmos., 106, 8013-8025, 2001.

Geyer, A., Alicke, B., Ackermann, R., Martinez, M., Harder, H., Brune, W., di Carlo, P., Williams, E., Jobson, T., Hall, S., Shetter, R., and Stutz, J.: Direct observations of daytime $\mathrm{NO}_{3}$ : Implications for urban boundary layer chemistry, J. Geophys. Res.Atmos., 108, 4368, doi:10.1029/2002JD002967, 2003.

Guo, J., Tilgner, A., Yeung, C., Wang, Z., Louie, P. K. K., Luk, C. W. Y., Xu, Z., Yuan, C., Gao, Y., Poon, S., Herrmann, H., Lee, S., Lam, K. S., and Wang, T.: Atmospheric Peroxides in a Polluted Subtropical Environment: Seasonal Variation, Sources and Sinks, and Importance of Heterogeneous Processes, Environ. Sci. Technol., 48, 1443-1450, 2014.

Hofzumahaus, A., Rohrer, F., Lu, K. D., Bohn, B., Brauers, T., Chang, C. C., Fuchs, H., Holland, F., Kita, K., Kondo, Y., Li, X., Lou, S. R., Shao, M., Zeng, L. M., Wahner, A., and Zhang, Y. H.: Amplified Trace Gas Removal in the Troposphere, Science, 324, 1702-1704, 2009.

Jenkin, M. E., Saunders, S. M., Wagner, V., and Pilling, M. J.: Protocol for the development of the Master Chemical Mecha- 
nism, MCM v3 (Part B): tropospheric degradation of aromatic volatile organic compounds, Atmos. Chem. Phys., 3, 181-193, doi:10.5194/acp-3-181-2003, 2003.

Li, Y., Lau, A. K. H., Fung, J. C. H., Zheng, J. Y., Zhong, L. J., and Louie, P. K. K.: Ozone source apportionment (OSAT) to differentiate local regional and super-regional source contributions in the Pearl River Delta region, China, J. Geophys. Res.-Atmos., 117, D15305, doi:10.1029/2011JD017340, 2012.

Ling, Z. H., Guo, H., Lam, S. H. M., Saunders, S. M., and Wang, T.: Atmospheric photochemical reactivity and ozone production at two sites in Hong Kong: Application of a Master Chemical Mechanism-photochemical box model, J. Geophys. Res.Atmos., 119, 10567-10582, doi:10.1002/2014JD021794, 2014.

Liu, Z., Wang, Y., Gu, D., Zhao, C., Huey, L. G., Stickel, R., Liao, J., Shao, M., Zhu, T., Zeng, L., Amoroso, A., Costabile, F., Chang, C.-C., and Liu, S.-C.: Summertime photochemistry during CAREBeijing-2007: $\mathrm{RO}_{\mathrm{x}}$ budgets and $\mathrm{O}_{3}$ formation, Atmos. Chem. Phys., 12, 7737-7752, doi:10.5194/acp-12-77372012, 2012.

Lou, S., Holland, F., Rohrer, F., Lu, K., Bohn, B., Brauers, T., Chang, C. C., Fuchs, H., Häseler, R., Kita, K., Kondo, Y., Li, X., Shao, M., Zeng, L., Wahner, A., Zhang, Y., Wang, W., and Hofzumahaus, A.: Atmospheric $\mathrm{OH}$ reactivities in the Pearl River Delta - China in summer 2006: measurement and model results, Atmos. Chem. Phys., 10, 11243-11260, doi:10.5194/acp-10-11243-2010, 2010.

Lu, K. D., Rohrer, F., Holland, F., Fuchs, H., Bohn, B., Brauers, T., Chang, C. C., Häseler, R., Hu, M., Kita, K., Kondo, Y., Li, X., Lou, S. R., Nehr, S., Shao, M., Zeng, L. M., Wahner, A., Zhang, Y. H., and Hofzumahaus, A.: Observation and modelling of $\mathrm{OH}$ and $\mathrm{HO}_{2}$ concentrations in the Pearl River Delta 2006: a missing $\mathrm{OH}$ source in a VOC rich atmosphere, Atmos. Chem. Phys., 12, 1541-1569, doi:10.5194/acp-12-1541-2012, 2012.

Lu, K. D., Rohrer, F., Holland, F., Fuchs, H., Brauers, T., Oebel, A., Dlugi, R., Hu, M., Li, X., Lou, S. R., Shao, M., Zhu, T., Wahner, A., Zhang, Y. H., and Hofzumahaus, A.: Nighttime observation and chemistry of $\mathrm{HO}_{\mathrm{x}}$ in the Pearl River Delta and Beijing in summer 2006, Atmos. Chem. Phys., 14, 4979-4999, doi:10.5194/acp-14-4979-2014, 2014

Martinez, M., Harder, H., Kovacs, T. A., Simpas, J. B., Bassis, J., Lesher, R., Brune, W. H., Frost, G. J., Williams, E. J., Stroud, C. A., Jobson, B. T., Roberts, J. M., Hall, S. R., Shetter, R. E., Wert, B., Fried, A., Alicke, B., Stutz, J., Young, V. L., White, A. B., and Zamora, R. J.: $\mathrm{OH}$ and $\mathrm{HO}_{2}$ concentrations, sources, and loss rates during the Southern Oxidants Study in Nashville, Tennessee, summer 1999, J. Geophys. Res.-Atmos., 108, 4617, doi:10.1029/2003JD003551, 2003.

Michoud, V., Kukui, A., Camredon, M., Colomb, A., Borbon, A., Miet, K., Aumont, B., Beekmann, M., Durand-Jolibois, R., Perrier, S., Zapf, P., Siour, G., Ait-Helal, W., Locoge, N., Sauvage, S., Afif, C., Gros, V., Furger, M., Ancellet, G., and Doussin, J. F.: Radical budget analysis in a suburban European site during the MEGAPOLI summer field campaign, Atmos. Chem. Phys., 12, 11951-11974, doi:10.5194/acp-12-11951-2012, 2012.

Ren, X. R., Harder, H., Martinez, M., Lesher, R. L., Oliger, A., Simpas, J. B., Brune, W. H., Schwab, J. J., Demerjian, K. L., He, Y., Zhou, X. L., and Gao, H. G.: $\mathrm{OH}$ and $\mathrm{HO}_{2}$ chemistry in the urban atmosphere of New York City, Atmos. Environ., 37, 3639-3651, 2003.
Rollins, A. W., Browne, E. C., Min, K. E., Pusede, S. E., Wooldridge, P. J., Gentner, D. R., Goldstein, A. H., Liu, S., Day, D. A., Russell, L. M., and Cohen, R. C.: Evidence for $\mathrm{NO}_{x}$ Control over Nighttime SOA Formation, Science, 337, 1210-1212, 2012.

Saunders, S. M., Jenkin, M. E., Derwent, R. G., and Pilling, M. J.: Protocol for the development of the Master Chemical Mechanism, MCM v3 (Part A): tropospheric degradation of nonaromatic volatile organic compounds, Atmos. Chem. Phys., 3, 161-180, doi:10.5194/acp-3-161-2003, 2003.

Sheehy, P. M., Volkamer, R., Molina, L. T., and Molina, M. J.: Oxidative capacity of the Mexico City atmosphere - Part 2: $\mathrm{A} \mathrm{RO}_{\mathrm{x}}$ radical cycling perspective, Atmos. Chem. Phys., 10, 6993-7008, doi:10.5194/acp-10-6993-2010, 2010.

Simpson, I. J., Blake, N. J., Barletta, B., Diskin, G. S., Fuelberg, H. E., Gorham, K., Huey, L. G., Meinardi, S., Rowland, F. S., Vay, S. A., Weinheimer, A. J., Yang, M., and Blake, D. R.: Characterization of trace gases measured over Alberta oil sands mining operations: 76 speciated $\mathrm{C}_{2}-\mathrm{C}_{1} 0$ volatile organic compounds (VOCs), $\mathrm{CO}_{2}, \mathrm{CH}_{4}, \mathrm{CO}, \mathrm{NO}, \mathrm{NO}_{2}, \mathrm{NO}_{\mathrm{y}}, \mathrm{O}_{3}$ and $\mathrm{SO}_{2}$, Atmos. Chem. Phys., 10, 11931-11954, doi:10.5194/acp-10-11931-2010, 2010.

Slusher, D. L., Huey, L. G., Tanner, D. J., Flocke, F. M., and Roberts, J. M.: A thermal dissociation-chemical ionization mass spectrometry (TD-CIMS) technique for the simultaneous measurement of peroxyacyl nitrates and dinitrogen pentoxide, J. Geophys. Res.-Atmos., 109, D19315, doi:10.1029/2004JD004670, 2004.

Stone, D., Whalley, L. K., and Heard, D. E.: Tropospheric OH and $\mathrm{HO}_{2}$ radicals: field measurements and model comparisons, Chem. Soc. Rev., 41, 6348-6404, 2012.

Tham, Y. J., Yan, C., Xue, L. K., Zha, Q. Z., Wang, X. F., and Wang, T.: Presence of high nitryl chloride in Asian coastal environment and its impact on atmospheric photochemistry, Chinese Sci. Bull., 59, 356-359, 2014.

Volkamer, R., Sheehy, P., Molina, L. T., and Molina, M. J.: Oxidative capacity of the Mexico City atmosphere - Part 1: A radical source perspective, Atmos. Chem. Phys., 10, 6969-6991, doi:10.5194/acp-10-6969-2010, 2010.

Wang, T., Poon, C. N., Kwok, Y. H., and Li, Y. S.: Characterizing the temporal variability and emission patterns of pollution plumes in the Pearl River Delta of China, Atmos. Environ., 37, 3539-3550, 2003.

Wang, T., Wei, X. L., Ding, A. J., Poon, C. N., Lam, K. S., Li, Y. S. Chan, L. Y., and Anson, M.: Increasing surface ozone concentrations in the background atmosphere of Southern China, 19942007, Atmos. Chem. Phys., 9, 6217-6227, doi:10.5194/acp-96217-2009, 2009.

Wang, X., Wang, T., Yan, C., Tham, Y. J., Xue, L., Xu, Z., and Zha, Q.: Large daytime signals of $\mathrm{N}_{2} \mathrm{O}_{5}$ and $\mathrm{NO}_{3}$ inferred at $62 \mathrm{amu}$ in a TD-CIMS: chemical interference or a real atmospheric phenomenon?, Atmos. Meas. Tech., 7, 1-12, doi:10.5194/amt-7-12014, 2014.

Whalley, L. K., Stone, D., Bandy, B., Dunmore, R., Hamilton, J. F., Hopkins, J., Lee, J. D., Lewis, A. C., and Heard, D. E.: Atmospheric $\mathrm{OH}$ reactivity in central London: observations, model predictions and estimates of in situ ozone production, Atmos. Chem. Phys., 16, 2109-2122, doi:10.5194/acp-16-2109-2016, 2016. 
Wood, E. C., Herndon, S. C., Onasch, T. B., Kroll, J. H., Canagaratna, M. R., Kolb, C. E., Worsnop, D. R., Neuman, J. A., Seila, R., Zavala, M., and Knighton, W. B.: A case study of ozone production, nitrogen oxides, and the radical budget in Mexico City, Atmos. Chem. Phys., 9, 2499-2516, doi:10.5194/acp-9-24992009, 2009.

Xu, Z., Wang, T., Xue, L. K., Louie, P. K. K., Luk, C. W. Y., Gao, J., Wang, S. L., Chai, F. H., and Wang, W. X.: Evaluating the uncertainties of thermal catalytic conversion in measuring atmospheric nitrogen dioxide at four differently polluted sites in China, Atmos. Environ., 76, 221-226, 2013.

Xu, Z., Wang, T., Wu, J. Q., Xue, L. K., Chan, J., Zha, Q. Z., Zhou, S. Z., Louie, P. K. K., and Luk, C. W. Y.: Nitrous acid (HONO) in a polluted subtropical atmosphere: Seasonal variability, direct vehicle emissions and heterogeneous production at ground surface, Atmos. Environ., 106, 100-109, 2015.

Xue, L. K., Wang, T., Zhang, J. M., Zhang, X. C., Deliger, Poon, C. N., Ding, A. J., Zhou, X. H., Wu, W. S., Tang, J., Zhang, Q. Z., and Wang, W. X.: Source of surface ozone and reactive nitrogen speciation at Mount Waliguan in western China: New insights from the 2006 summer study, J. Geophys. Res.-Atmos., 116, D07306, doi:10.1029/2010JD014735, 2011.

Xue, L. K., Wang, T., Guo, H., Blake, D. R., Tang, J., Zhang, X. C., Saunders, S. M., and Wang, W. X.: Sources and photochemistry of volatile organic compounds in the remote atmosphere of western China: results from the Mt. Waliguan Observatory, Atmos. Chem. Phys., 13, 8551-8567, doi:10.5194/acp-13-85512013, 2013.

Xue, L. K., Wang, T., Gao, J., Ding, A. J., Zhou, X. H., Blake, D. R., Wang, X. F., Saunders, S. M., Fan, S. J., Zuo, H. C., Zhang, Q. Z., and Wang, W. X.: Ground-level ozone in four Chinese cities: precursors, regional transport and heterogeneous processes, Atmos. Chem. Phys., 14, 13175-13188, doi:10.5194/acp14-13175-2014, 2014a.
Xue, L. K., Wang, T., Louie, P. K. K., Luk, C. W. Y., Blake, D. R., and $\mathrm{Xu}, \mathrm{Z}$.: Increasing External Effects Negate Local Efforts to Control Ozone Air Pollution: A Case Study of Hong Kong and Implications for Other Chinese Cities, Environ. Sci. Technol., 48, 10769-10775, 2014b.

Xue, L. K., Wang, T., Wang, X. F., Blake, D. R., Gao, J., Nie, W., Gao, R., Gao, X. M., Xu, Z., Ding, A. J., Huang, Y., Lee, S. C., Chen, Y. Z., Wang, S. L., Chai, F. H., Zhang, Q. Z., and Wang, W. $X .:$ On the use of an explicit chemical mechanism to dissect peroxy acetyl nitrate formation, Environ. Pollut., 195, 39-47, 2014c.

Xue, L. K., Saunders, S. M., Wang, T., Gao, R., Wang, X. F., Zhang, Q. Z., and Wang, W. X.: Development of a chlorine chemistry module for the Master Chemical Mechanism, Geosci. Model Dev., 8, 3151-3162, doi:10.5194/gmd-8-3151-2015, 2015.

Zhang, J., Wang, T., Chameides, W. L., Cardelino, C., Kwok, J., Blake, D. R., Ding, A., and So, K. L.: Ozone production and hydrocarbon reactivity in Hong Kong, Southern China, Atmos. Chem. Phys., 7, 557-573, doi:10.5194/acp-7-557-2007, 2007.

Zhang, Y. H., Su, H., Zhong, L. J., Cheng, Y. F., Zeng, L. M., Wang, X. S., Xiang, Y. R., Wang, J. L., Gao, D. F., Shao, M., Fan, S. J., and Liu, S. C.: Regional ozone pollution and observation-based approach for analyzing ozone-precursor relationship during the PRIDE-PRD2004 campaign, Atmos. Environ., 42, 6203-6218, 2008.

Zheng, J. Y., Zhong, L. J., Wang, T., Louie, P. K. K., and Li, Z. C.: Ground-level ozone in the Pearl River Delta region: Analysis of data from a recently established regional air quality monitoring network, Atmos. Environ., 44, 814-823, 2010.

Zhou, S. Z., Wang, T., Wang, Z., Li, W. J., Xu, Z., Wang, X. F., Yuan, C., Poon, C. N., Louie, P. K. K., Luk, C. W. Y., and Wang, W. X.: Photochemical evolution of organic aerosols observed in urban plumes from Hong Kong and the Pearl River Delta of China, Atmos. Environ., 88, 219-229, 2014. 